Print ISSN: 2288-4637 / Online ISSN 2288-4645

doi:10.13106/jafeb.2019.vol6.no3.247

\title{
Factors Affecting Brand and Student Decision Buying Fresh Milk: A Case Study in Ho Chi Minh City, Vietnam
}

\author{
Huan Quang NGO1, Thang Quyet NGUYEN²*, Nguyen Thanh LONG ${ }^{3}$, \\ Tung Van TRAN ${ }^{4}$, Tri M. HOANG
}

Received: June 22, 2019 Revised: June 30, 2019 Accepted: July 17, 2019

\begin{abstract}
The paper aims to examine the factors affecting brand and student decision in buying fresh milk. Combining qualitative and quantitative research methods, this study used self-completed questionnaires to investigate 520 students in Ho Chi Minh City. The results of the study show that that there are five key determinants affecting the dairy brand and student decision in buying fresh milk, including: (1) product quality, (2) fair price, (3) product promotion and customer services, (4) product convenience, and (5) reference group's attitude to the brand. In addition, it is also found that product brand has a direct and positive impact on the student decision. The finding in this study is quite different from other existing literatures in terms of the importance level of the determinants of the student decision in buying fresh milk; specifically, in deciding to buy their fresh milk, students are often interested in the promotion and customer service, the product convenience, and the reference group for the purchase, more than in the quality and price of the product. From these findings, some managerial implications are proposed for policy-makers and relevant enterprises to have appropriate policies and strategies for their business development.
\end{abstract}

Keywords: Consumer Behaviour, Buying Decision, Fresh Milk, Brand, Ho Chi Minh City, Vietnam.

JEL Classification Code: M31, M37, D7, C5.

1 First Author. Dean, School of Management, University of Economics Ho Chi Minh City (UEH), Vietnam.

Email: ngoqhuan@ueh.edu.vn

2 Corresponding Author. Associate Professor and Dean, Faculty of Tourism and Hospitality Management, Ho Chi Minh City University of Technology (HUTECH), Vietnam [Postal Address: 475A Dien Bien Phu Street, Ward 25, Binh Thanh District, Ho Chi Minh City, 700000, Vietnam]. Email: nq.thang@hutech.edu.vn

3 Dean, Faculty of Business Administration, Industry University of Ho Chi Minh City (IUH), Vietnam.

Email: nguyenthanhlong@iuh.edu.vn

4 Dean, Faculty of Accounting - Finance - Banking, Ho Chi Minh City University of Technology (HUTECH), Vietnam.

Email: tv.tung@hutech.edu.vn

$5 \mathrm{PhD}$ Student, School of Economics and Finance (Albany),

Massey Business School, Massey University, New Zealand.

Email:m.hoang@massey.ac.nz

(๑) Copyright: Korean Distribution Science Association (KODISA)

This is an Open Access article distributed under the terms of the Creative Commons Attribution NonCommercial License (https://creativecommons.org/licenses/by-nc/4.0/) which permits unrestricted noncommercial use, distribution, and reproduction in any medium, provided the original work is properly cited.

\section{Introduction}

Vietnam is a potential market for dairy producers and has been experiencing unprecedented growth in recent years, with the rate of growth increasing every year. On average, the dairy sector grew by $17 \%$ per annum during the period from 2011 to 2015 (Agroinfo, 2016). By the end of 2017, the total turnover in the dairy sector exceeded VND 100,000 billion $^{2}$, up more than 5\% from 2016 (VND 95,000 billion) (Vietnam Dairy Association, 2018). The growth of the dairy sector can be explained by the fact that Vietnam is a densely populated country with a high population growth rate of $1.2 \%$ per year, and its per capita income is constantly increasing. The GDP growth rate of $6 \%-8 \%$ per annum and the increase in per capita income of $14.2 \%$ per year, along with the trends of improving health and height for Vietnamese people, mean that the demand for the consumption of dairy products is always high (Invest

\footnotetext{
2 Note: VND $(23.000=1$ USD) (at the time of this writing)
} 
Vietnam, 2016). The average annual milk consumption per capita in Vietnam in 2015 was about 23 litres, while in 2010 it was 12 litres. For the period from 2010 to 2015 , Vietnamese people consumed about 15 litres of milk per year on average (Invest Vietnam, 2016). Thus, the demand for dairy products in general, and for milk in particular, is growing. Domestic dairy producers have made great efforts to modernize their production lines as well as to improve the quality of their produce, to meet the needs of consumers. However, as Vietnam integrates rapidly into the world, the dairy market has become more competitive. Domestic dairy producers have to compete with foreign brands in their home markets. In such context of fierce competition, it is important to have a thorough understanding of the choices of customers to have the appropriate strategies in satisfying diverse consuming demands on the market. Therefore, getting to identify the determinants of the consumer's decision in buying their milk is critical for the survival and growth of all players on the marketplace. In order to promote the health of the population and increase the height of Vietnamese people, Vietnam Government has taken great care to promote the consumption of milk by the people (Ministry of Health of Vietnam, 2015). The Government has approved the Master plan for physical strength and height of the Vietnamese people in the period 2011-2030, which includes specific programmes and action plans (Vietnam Government, 2011); among which, university students, in particular, are encouraged to drink more milk in order to improve their physical and intellectual condition because students are considered as the intellectual elite, the future owner of the country (Ministry of Health of Vietnam, 2015). Many dairy firms participating in these programmes offer different dairy product categories including fresh milk; thus, students have a variety of choices among the brands and categories for their demands. One of the major difficulties for domestic dairy producers is that Vietnamese consumers in general, and students in particular, are more interested in foreign brands than in domestic brands (Vietnam Dairy Association, 2018).

One of the product lines for which foreign brands appear in the Vietnamese market is fresh milk. Previously, this market had mainly belonged to Vinamilk and Friesland Campina, with smaller segments of the market split between smaller competitors such as Long Thanh, Da Lat, Moc Chau and $\mathrm{Ba}$ Vi. In addition, there are brands like TH True Milk and NutiFood, and dozens of brands of fresh milk imported from abroad (Agroinfo, 2016). Hence, this study aims at investigating the factors affecting the fresh milk brand and buying decision from students' perspective. Due to constrained resources available, we limited our research object within Ho Chi Minh City because it has the largest number of students in comparison with other cities/provinces in Vietnam (GSO, 2017). From the identified factors, we propose some managerial implications to help not only fresh milk suppliers enhance their brand value and consumption volume but also government agencies to create proper regulations and directions to help students choose their suitable milk brand. We expect our proposals to be workable to some other countries having similar economic situation as of Vietnam.

\section{Literature Review and Research Model}

\subsection{Literature Review}

\subsubsection{Brand and Its Determinants}

The term "brand" has been differently defined across scholars. For example, Kotler (1994) and Kotler and Keller (2016) defined it as a name, term, sign, symbol or design, or a combination of all of these that distinguishes the goods or services of a seller from those of its competitors while Clifton and Simons (2003) considered it as a set of tangible and intangible attributes, symbolized by a trade name which creates positive influence and value once managed properly. Kotler and Pfoertsch (2006) claimed that a brand is a successful medium for conveying the advantages and value that a service can provide because brand is a guarantee of quality, source and capacity, and thus it increases the awareness and reduces the risk and complexity associated with purchasing decisions. And Leek and Christodoulides (2012) argued that brands have emotional and personal value, and capture a customer's imagination; thus, the value of a brand lies in how it delivers emotional qualities that help customers in their decision-making, in addition to having functional qualities. Brand relevance is an important aspect of the success of a product (Fernandes, Chaudhuri, \& Vidyasagar, 2017). Branding is important for strategic success and market dynamics.

\subsubsection{Determinants of Consumer Decision}

\section{a) Brand and its impacts on customer's decision}

According to Lee and Leh (2011), a certain brand normally has the following symbolic attributes: (1) Social image which is considered as the consumer's perception of the brand esteem; (2) Perceived value of the brand equity in term of the paid price for a product and all its utilities; (3) Trustworthiness which is referred to as the level of confidence consumer places in the organization of the brand; and (4) Country-of-origin, referred to origin of a firm manufacturing the product, can influence perceived quality 
and brand loyalty. Therefore, it could be said that brand has a significant impact on the buyer's decision-making process. A brand can create excitement and passion in the buyer's emotional state (Kotler \& Armstrong, 2010). A satisfied consumer tends to be loyal to their selected brand because their buying decision can be made with little or no effort, gradually becoming their buying habit (Solomon, 2004). In addition, Ajay and Murthi (2008) pointed that customers prefer to buy products/services from a well-known or familiar brand because they are usually risk averters in trying unknown and new brands. As such, getting the trust in the quality from the customers is critical in having repurchased from the customers. However, the consumers easily switch to other brands when they feel unsatisfied with the current brand or simply want to try new brands which offer better price, better quality, better functions, more attractive appearance, etc. through their appealing advertisements. However, if the actual performance of the product or service fails to satisfy their expectation, the new brand usually loses its customers quickly (Perreau, 2014).

Moreover, Bolton and James (1991) pointed that customer's decision on buying a product/service is affected by the perceived quality of a brand which is defined as "the customer's perception of the overall quality or superiority of a product or service with respect to its intended purpose, relative to alternatives" (Zeithaml, 1998). It is because the quality perception is the key source of their belief in making their correct decision. Aaker (1996) claimed that once customers had negative impression about the quality of a product/service of a certain brand previously used, i.e. they had some previous unpleasant experiences, they tend to lose their trust in buying related product/service offered by the same brand though their quality has been significantly improved. Consequently, continuous improvement of perceived quality of a brand has been considered as a preferred development strategy in several companies over the last few decades (Aaker, 1991). Literally, there are still many other studies investigating the impacts of brands on consumer's decision-making process to buy products/ services (Bui \& Nguyen, 2012; Thoma, Kapaj, Boshnjaku, \& Muca, 2017; Tuan, Phuong, Ngoc, \& Mai, 2013). As per our knowledge, no similar studies have been conducted in the domain of fresh milk in Vietnam.

\section{b) Other determinants}

Practically, in deciding to buy a product/service, a consumer normally goes through a complex process which takes some time and effort before the final decision is made. Kotler and Armstrong (2010) found that a general decisionmaking process has five key stages, including: (1) Identifying self needs and problem awareness; (2) Searching for relevant information; (3) Evaluating possible alternatives; (4) Purchasing; and (5) Evaluating the performance after purchase. They also found that there are several factors affecting the process. Such factors are classified into three major groups, including: (1) personal characteristics (age and life cycle state, occupation, economic situation, lifestyle, and personality and selfconcept, etc.); (2) psychological characteristics (motivation, perception, learning, and beliefs and attitudes, etc.) and (3) social factors (reference groups, family, their role and position in the social groups) which is similar to these by Perreau (2014).

Foxall and Sigurdsson (2013) claimed that the consumer decision is likely affected by two main areas, including: (1) product and brand preference; and (2) contextual influence. Specifically, product and brand preference helps consumers to maximize their requirements before making their final decision; i.e. those seeking accomplishment tend to buy high-value and branded products while those purchasing for maintenance tend to buy product at a fair price. As such, fair price is one of the determinants to be considered in our study in the case of fresh milk. In addition, consumers are usually affected by contextual factors, including discounts, promotions and their personal experience from previous purchase (Oliveira \& Castro, 2016; Foxall \& Sigurdsson, 2013). On the other hand, in the flat world of social media platforms, consumers are interchangeably influenced each other during their gathering information about the brands. The endorsement or critics of certain brands from the platforms or word-of-mouth significantly affect the final decision of a consumer (Lee \& Ma, 2012). The view of the consumer who affects other consumers is a growing trend for the manner in which consumers gather information. Such factor is referred to as the reference group's attitude to the brand.

Moreover, Ishak and Zabil (2012) found that consumer awareness has positive impacts on their buying decisions; lack of awareness usually leads consumers to ignorantly purchase or reduce their ability to protect their rights against sellers' expropriations. Meanwhile, Goodhope (2012) pointed that price elasticity demand also significantly affects consumer's buying decision. Elastic products are those whose demand is seriously affected by the fluctuation of their prices. For example, their demand is sharply dropped once their prices are increased and consumers tend to switch to alternative products/services; on the contrary, inelastic products are those whose demand are more likely to remain part of the consumers' consumption patterns, regardless of the increases in their prices (Goodhope, 2012). Despite of the increase in the prices of these products, for example bread, milk, maize, gas/petrol and other essentials, consumers are more likely to continue to buy them.

In the case of milk consumption in Ho Chi Minh City, Bui and Nguyen (2012) investigated the main factors affecting 
the decision of consumers in choosing infant formula for a baby. Their findings showed that the decision to choose infant formula for a baby is influenced by the product quality, the product price, the image of the supplier, and the reference group. However, this result changes according to the brands of powdered milk though the powdered milk is domestic or imported, and the educational levels of the customers. Similarly, research on infant formula by Suroto, Fanani, and Nugroho (2013) found that the decision to buy infant formula in Malang, Indonesia is positively affected by culture, psychology, society, and the individual, while price movement has a negative effect on the consumer's decision. This proves that a lower price (soft price) is not ideal if customers are to be encouraged to choose milk in the city of Malang, Indonesia. Similarly, Hong (2015) claimed that the decision to buy milk powder for children in Hanoi is influenced by cultural, societal, psychological and individual, further agreeing with these by Kotler and Armstrong (2010) and Perreau (2014).

Literally, through the reviews of existing literatures, several determinants affecting consumer's decision have been identified, including product quality (Andreti, Zhafira, Akmal, \& Kumar, 2013; Kumar \& Babu, 2014), product promotion (Andreti et al., 2013), product brand (Krešić et al., 2010; Kumar \& Babu, 2014; Tuan et al., 2013), customer support and after-sale services (Chigamba \& Fatoki, 2011), product convenience (Chigamba \& Fatoki, 2011), reference group (Santoso, Setiadi, Kisworo, \& Nuswantara, 2012), shop's area and location (Andreti et al., 2013), household size, income and average age (Bingham, Dharmasena, Capps, \& Salin, 2014; Kuma, Baker, Getnet, \& Kassa, 2012).

\subsection{Research Model}

The proposed model is based on the theory of reasoned action (TRA), Ajzen's behavioural theory of intentions (Ajzen \& Fishbein, 1980), the work of Andreti et al. (2013), Bui and Nguyen (2012), Chigamba and Fatoki (2011), Kotler (1994) and others, and the opinions of experts and researchers. The proposed research model is shown in Figure 1.

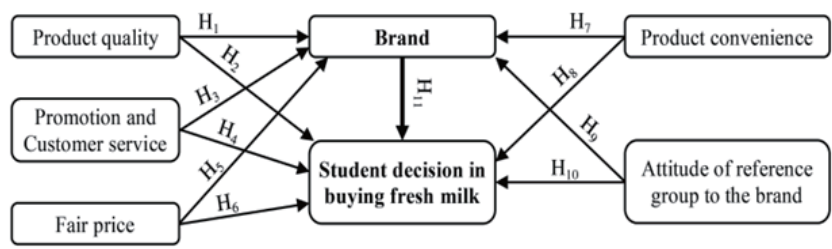

Figure 1: Research model

\subsubsection{Product Quality}

Product quality is reflected in the variety of brands, their types, an attractive design and convenience for use. According to Andreti et al. (2013), and Kumar and Babu (2014), product quality has a strong impact on consumer purchasing decisions.

H1: Product quality has a positive relationship with the dairy brand.

H2: Product quality has a positive relationship with the student decision in buying fresh milk.

\subsubsection{The Promotion and Customer Service}

According to Chigamba and Fatoki (2011), product promotion uses marketing tools such as communication, advertising, promotion and sponsorship of the manufacturer, which affect the perception, emotions, and feelings of customers. According to Andreti et al. (2013), customer service represents the level of customer satisfaction and the reliability of the service provider through the store employees' morale, attitudes, and capabilities for store services and procedures, and procedures for delivery and receipt of goods. The better the customer service for a product (service), the higher the probability that customers will repeat the choice of product (service) when they have shopping needs.

H3: Promotion and customer service have a positive relationship with the dairy brand.

H4: Promotion and customer service have a positive relationship with the student decision in buying fresh milk.

\subsubsection{Fair Price}

The product price is the amount of money a consumer spends to use a product or service. High prices may become a barrier to the purchase of consumer products or services (McEachern \& Schröder, 2002; Padel \& Foster, 2005). A fair price is expressed by considering the price strategy, the price policy for the products, and the services of the shop compared to others. A fair price is the price that matches the product quality. A fair price is also stable, competitive and suitable for the consumer's income.

H5: Fair price has a positive relationship with the dairy brand.

H6: Fair price has a positive relationship with the student decision in buying fresh milk. 


\subsubsection{Product Convenience}

Product convenience is considered in terms of the space, time and procedure for shopping. It also refers to the distribution network of stores and the convenience of shopping locations, product supply timing, opening hours, and convenience in the shopping process. These conditions allow customers to reach the products they want easily. According to Chigamba and Fatoki (2011), product convenience has a significant impact on customers' choice of where to shop. In particular, the more convenience stores offer customers, the more customers choose them as their shopping locations.

H7: Product convenience has a positive relationship with the dairy brand.

H8: Product convenience has a positive relationship with the student decision in buying fresh milk.

\subsubsection{Reference Group's Attitude to the Brand (Reference Group)}

Recommendations from others, or the influence of reference groups, also known as subjective standards or social influences, are perceived as the perceptions of the attitudes of those around them who agree or disagree with a customer's choice. The reference group is shown by the experiences and opinions of relatives, friends or colleagues, etc. Customers rely on reference groups before deciding on a product or service.

H9: Reference group has a positive relationship with the dairy brand.

H10: Reference group has a positive relationship with the student decision in buying fresh milk.

As was indicated in Section 2.1.1, the dairy brand influences consumers' shopping behaviour. Hence, our hypothesis $\mathrm{H} 11$ is posited as follows:
H11: Dairy brand has a positive relationship with the student decision in buying fresh milk.

\section{Research Methodology}

The research scope is Ho Chi Minh City, the largest urban centre in Vietnam and an important political, economic, cultural and scientific centre in Vietnam. The city territory stretches from northwest to southeast, and lies between $10^{\circ} 22^{\prime} 13^{\prime \prime}$ and $11^{\circ} 22^{\prime} 17^{\prime \prime}$ north and $106^{\circ} 01^{\prime} 25^{\prime \prime}$ and $107^{\circ} 01^{\prime} 10^{\prime \prime}$ east. According to the General Statistics Office (2018), the number of universities in the City is over 40 , and the average student population ranges from 11,000 (the smallest university) to 20,000 (the largest university). The minimum age for entry to university in Vietnam is 18 years.

We conducted this study in three phases. The first phase was for a qualitative research in which we interviewed 8 experts from two large brands of fresh milk on the market and discussing in groups with 32 students to improve the factor scales and design a survey questionnaire for our pilot test which was used as a refinery tool for our final version to conduct official survey in two months, September - October, 2018. The self-completed questionnaire officially used in this study consists of items as shown in Table 1.

According to Hair, Anderson, Tatham, and Black (2006), in order to have reliable representation of the population, sample size must be at least $m \times 5$, where $m$ is the number of independent variables. Thus, for the 33 independent variables in this study, the sample size must be at least 165 . However, to ensure high reliability, we conducted an official survey with 1,240 respondents who were being students from Industrial University of Ho Chi Minh City (IUH) and Ho Chi Minh City of Technology (HUTECH), during September 2018 - October 2018. There were totally 746 completed questionnaires collected; among which there were 226 pieces invalid. As such, only 520 valid responses are used in our data analysis.

Table 1: Investigated factors and their corresponding items

\begin{tabular}{|c|c|l|}
\hline Factors & Code & \multicolumn{1}{c|}{ Investigated variables and related research } \\
\hline \multirow{4}{*}{$\begin{array}{l}\text { Product } \\
\text { Quality }\end{array}$} & SP1 & The fresh milk product that you choose must be of good quality and reputation (Andreti et al., 2013). \\
\cline { 2 - 3 } & SP2 & The fresh milk product that you choose must be diverse and rich in design and types (Andreti et al., 2013). \\
\cline { 2 - 3 } & SP3 & $\begin{array}{l}\text { The fresh milk product that you choose must always be innovative in its label design and quality (Andreti et al., } \\
\text { 2013). }\end{array}$ \\
\cline { 2 - 3 } & SP4 & The fresh milk product that you choose must be environmentally friendly (expert opinion) \\
\cline { 2 - 4 } & SP5 & $\begin{array}{l}\text { The fresh milk product that you choose must have more diverse flavours than other competing products (Andreti et } \\
\text { al., 2013). }\end{array}$ \\
\cline { 2 - 3 } & SP6 & $\begin{array}{l}\text { The fresh milk product that you choose must have a more eye-catching label design than other competing } \\
\text { products (Andreti et al., 2013). }\end{array}$ \\
\hline \multirow{5}{*}{ Fair Price } & GC1 & $\begin{array}{l}\text { The price of the fresh milk product that you choose must be flexible for each product line (Andreti et al., 2013; } \\
\text { Chigamba \& Fatoki, 2011). }\end{array}$ \\
\cline { 2 - 4 } & GC2 & $\begin{array}{l}\text { The fresh milk product that you choose must have a more competitive price than those of other products of the } \\
\text { same type (Andreti et al., 2013; Chigamba \& Fatoki, 2011). }\end{array}$ \\
\cline { 2 - 3 } & GC3 & The fresh milk product that you choose must have a preferential pricing policy for students (expert opinion). \\
\hline
\end{tabular}




\begin{tabular}{|c|c|c|}
\hline & GC4 & $\begin{array}{l}\text { The fresh milk product that you choose must have a steady price (Andreti et al., 2013; Chigamba and Fatoki, } \\
\text { 2011). }\end{array}$ \\
\hline & GC5 & $\begin{array}{l}\text { The fresh milk product that you choose must have a lower price when you buy in bulk (Andreti et al., 2013; } \\
\text { Chigamba \& Fatoki, 2011). }\end{array}$ \\
\hline \multirow{4}{*}{$\begin{array}{l}\text { Product } \\
\text { convenienc } \\
\text { e }\end{array}$} & TT1 & $\begin{array}{l}\text { The fresh milk product that you choose must have an easy-to-use design (Andreti et al., 2013; Bui \& Nguyen, } \\
\text { 2012; Chigamba \& Fatoki, 2011). }\end{array}$ \\
\hline & TT2 & $\begin{array}{l}\text { The fresh milk product that you choose must be easy to find and convenient to buy (Andreti et al., 2013; Bui \& } \\
\text { Nguyen, 2012; Chigamba \& Fatoki, 2011). }\end{array}$ \\
\hline & TT3 & $\begin{array}{l}\text { The information about the fresh milk product you choose must be specific and clear (Andreti et al., 2013; Bui \& } \\
\text { Nguyen, 2012; Chigamba \& Fatoki, 2011). }\end{array}$ \\
\hline & TT4 & $\begin{array}{l}\text { The fresh milk product that you choose must be easy and convenient to store (Andreti et al., 2013; Chigamba \& } \\
\text { Fatoki, 2011). }\end{array}$ \\
\hline \multirow{5}{*}{$\begin{array}{l}\text { Promotion } \\
\text { and } \\
\text { customer } \\
\text { service }\end{array}$} & CT1 & $\begin{array}{l}\text { The fresh milk product that you choose must have attractive advertising programmes (Andreti et al., 2013; Bui \& } \\
\text { Nguyen, 2012; Chigamba \& Fatoki, 2011). }\end{array}$ \\
\hline & CT2 & $\begin{array}{l}\text { The fresh milk product that you choose must often have attractive promotional programmes (Andreti et al., 2013; } \\
\text { Bui \& Nguyen, 2012; Chigamba \& Fatoki, 2011). }\end{array}$ \\
\hline & CT3 & The fresh milk product that students choose must often be in student-funding programmes (expert opinion). \\
\hline & CT4 & $\begin{array}{l}\text { The fresh milk product that you choose must regularly have gratitude programmes and attractive customer care } \\
\text { programmes (Andreti et al., 2013; Bui \& Nguyen, 2012; Chigamba \& Fatoki, 2011). }\end{array}$ \\
\hline & CT5 & $\begin{array}{l}\text { The fresh milk product that you choose must be supported by a very attentive and professional customer service } \\
\text { team (Andreti et al., 2013). }\end{array}$ \\
\hline \multirow{4}{*}{$\begin{array}{l}\text { Reference } \\
\text { group }\end{array}$} & TK1 & $\begin{array}{l}\text { You choose a fresh milk product on the basis of advice from relatives (Bui \& Nguyen, 2012; Chigamba \& Fatoki, } \\
\text { 2011). }\end{array}$ \\
\hline & TK2 & $\begin{array}{l}\text { You choose a fresh milk product on the basis of consultation with friends (Bui \& Nguyen, 2012; Chigamba \& } \\
\text { Fatoki, 2011). }\end{array}$ \\
\hline & TK3 & $\begin{array}{l}\text { You choose a fresh milk product on the basis of your own experience (Bui \& Nguyen, 2012; Chigamba \& Fatoki, } \\
\text { 2011). }\end{array}$ \\
\hline & TK4 & You choose a fresh milk product on the basis of mass media (Bui \& Nguyen, 2012; Chigamba \& Fatoki, 2011). \\
\hline \multirow{5}{*}{ Dairy brand } & TH1 & $\begin{array}{l}\text { The dairy brand of the fresh milk product that you choose must be well-known (Andreti et al., 2013; Bui \& Nguyen, } \\
2012 ; \text { Kotler, 1994). }\end{array}$ \\
\hline & $\mathrm{TH} 2$ & $\begin{array}{l}\text { The dairy brand of the fresh milk product that you choose must be long-standing (Andreti et al., 2013; Kotler, } \\
\text { 1994). }\end{array}$ \\
\hline & TH3 & $\begin{array}{l}\text { The dairy brand of the fresh milk product that you choose must be environmentally friendly (Andreti et al., 2013; } \\
\text { Bui \& Nguyen, 2012; Kotler, 1994). }\end{array}$ \\
\hline & TH4 & $\begin{array}{l}\text { The dairy brand of the fresh milk product that you choose must be the local brand (Andreti et al., 2013; Bui \& } \\
\text { Nguyen, 2012; Kotler, 1994). }\end{array}$ \\
\hline & TH5 & $\begin{array}{l}\text { The dairy brand of the fresh milk product that you choose must be popular (Andreti et al., 2013; Bui \& Nguyen, } \\
2012 ; \text { Kotler, 1994). }\end{array}$ \\
\hline \multirow{4}{*}{$\begin{array}{l}\text { Student } \\
\text { decision in } \\
\text { buying } \\
\text { fresh milk }\end{array}$} & QD1 & The decision to choose the fresh milk product that you are using is right (Andreti et al., 2013; Kotler, 1994). \\
\hline & QD2 & $\begin{array}{l}\text { In the future, you will continue to choose the fresh milk product that you are using (Andreti et al., 2013; Kotler, } \\
\text { 1994). }\end{array}$ \\
\hline & QD3 & You are ready to introduce your own fresh milk product to others (Kotler, 1994; Andreti et al., 2013). \\
\hline & QD4 & $\begin{array}{l}\text { You will not change your mind if you find a fresh milk product with better prices and quality (Andreti et al., 2013; } \\
\text { Kotler, 1994). }\end{array}$ \\
\hline
\end{tabular}

In the second phase, we conducted scale reliability analysis with Cronbach's Alpha coefficient and exploratory factor analysis (EFA) to test the internal consistency of the investigated scales. As a rule of thumb, the sample size should be at least five times of the number of observed variables to have sufficient evidence for its representation of the population (Hair et al., 2006). Due to the ease in approaching students, we directly delivered hard copies of our questionnaires to 1,240 students. The collected data were coded, screened and analyzed with SPSS and AMOS soft-wares. Literally, a scale is considered reliable if the corrected item-total correlation of all observed variables in a scale is greater than 0.3 and its Cronbach's Alpha coefficient is greater than 0.6 (Nunnally \& Bernstein, 1994). Additional criteria required in the EFA to make it validated include: (1) Eigenvalue $\geq 1$; (2) Total variance explained $\geq$ $50 \%$; (3) KMO $\geq 0.5$; (4) Sig. coefficient of the KMO test $\leq$ 0.05 ; (5) Factor loadings of all observed variables are $\geq 0.5$; and (6) Weight difference between the loadings of two factors > 0.3 (Hair et al., 2006; Nguyen, 2011; Long \& Nguyen, 2018).

In the third phase, we deployed Confirmatory Factor Analysis (CFA) to further assess the unidirectionality, scale reliability, convergence value and distinctive value; and used Structural Equation Modelling (SEM) to test the model fitness. Hair et al. (1998), and Steenkamp and Trijp (1991) proposed some key model parameters to be satisfied to consider a model suitable for market data, including: (1) significance value (Sig.) of Chi-square test is no more than $5 \%$; CMIN/df $\leq 2$ (in some cases, CMIN/df $\leq 3$ is also 
acceptable); GFI, TLI, CFI $\geq 0.9$. In addition, recent researchers suggest that GFI should be greater than 0.8 , RMSEA $\leq 0.08$, overall reliability should be $\geq 0.6$, and the extracted error should be $\geq 0.5$ (Hair et al., 1998).

\section{Empirical Findings}

\subsection{Descriptive Statistics}

Among the 520 valid observations, there were 290 males, accounting for $55.80 \%$; thus, only 230 female students joined our survey. Among them, we had 103 freshman students (10.20\%), 154 sophomores (33.50\%), 117 juniors $(22.5 \%)$, and 146 seniors $(33.8 \%)$. These figures indicate a quite balance state of the surveyed objects.

\subsection{Reliability of Measurement Scale}

By conducting scale reliability analyses for all of the seven independent and dependent factors, we found that the Cronbach's Alpha coefficients ( $\alpha$ ) of the seven scales shown in Table 2 are all greater than the required criteria of $\alpha \geq 0.6$ and all corrected item-total correlations $\geq 0.3$. However, as
TH5 has a low corrected item-total correlation of $0.187<$ 0.3 , it is therefore omitted from the $\mathrm{TH}$ scale. After eliminating TH5 from the scale, we conducted scale reliability test for the scale again and found that the scale met all required criteria to be included in the next exploratory factor analysis.

\subsection{Exploratory Factor Analysis (EFA)}

After the scale reliability tests, we further explore the internal consistency of the scales. First, we used 24 items as the measures of five independent factors to conduct exploratory factor analysis (EFA). The analysis results in Table 2 clearly show that the variables are categorized into five groups, with a cumulative variance of $67.608 \%$, larger than $50 \%$; KMO coefficient is 0.895 , larger than 0.5 and the significance level of the Bartlett's test is less than $1 \%$. As a result, these scales are appropriate and the EFA approach used in this study is valid. All factor loading values of the independent variables are greater than 0.5 , and the difference between two contingent factor loadings of the same item is greater than 0.3 , indicating that the extracted factors are all discriminant.

Table 2: Exploratory factor analysis of independent variables

\begin{tabular}{|c|c|c|c|c|c|c|c|c|}
\hline \multirow{2}{*}{ Code } & \multicolumn{5}{|c|}{ Factors } & \multirow{2}{*}{$\alpha$} & \multirow{2}{*}{$\begin{array}{c}\text { Corrected Item-Total } \\
\text { Correlation }\end{array}$} & \multirow{2}{*}{$\alpha$ if Item Deleted } \\
\hline & 1 & 2 & 3 & 4 & 5 & & & \\
\hline $\mathrm{SP}_{4}$ & 0.853 & & & & & \multirow{6}{*}{0.885} & \begin{tabular}{|l|}
0.744 \\
\end{tabular} & 0.858 \\
\hline $\mathrm{SP}_{5}$ & 0.823 & & & & & & 0.745 & 0.857 \\
\hline $\mathrm{SP}_{2}$ & 0.820 & & & & & & 0.727 & 0.860 \\
\hline $\mathrm{SP}_{3}$ & 0.814 & & & & & & 0.704 & 0.864 \\
\hline $\mathrm{SP}_{1}$ & 0.774 & & & & & & 0.687 & 0.867 \\
\hline $\mathrm{SP}_{6}$ & 0.691 & & & & & & 0.584 & 0.883 \\
\hline $\mathrm{GC}_{5}$ & & 0.884 & & & & \multirow{5}{*}{0.839} & 0.788 & 0.858 \\
\hline $\mathrm{GC}_{1}$ & & 0.864 & & & & & 0.745 & 0.867 \\
\hline $\mathrm{GC}_{4}$ & & 0.837 & & & & & 0.730 & 0.871 \\
\hline $\mathrm{GC}_{3}$ & & 0.798 & & & & & 0.710 & 0.876 \\
\hline $\mathrm{GC}_{2}$ & & 0.794 & & & & & 0.714 & 0.874 \\
\hline $\mathrm{CT}_{1}$ & & & 0.858 & & & \multirow{5}{*}{0.839} & 0.705 & 0.790 \\
\hline $\mathrm{CT}_{4}$ & & & 0.840 & & & & 0.720 & 0.787 \\
\hline $\mathrm{CT}_{3}$ & & & 0.801 & & & & 0.681 & 0.796 \\
\hline $\mathrm{CT}_{2}$ & & & 0.781 & & & & 0.685 & 0.795 \\
\hline $\mathrm{CT}_{5}$ & & & 0.615 & & & & 0.441 & 0.861 \\
\hline $\mathrm{TK}_{2}$ & & & & 0.905 & & \multirow{4}{*}{0.875} & 0.719 & 0.705 \\
\hline $\mathrm{TK}_{3}$ & & & & 0.851 & & & 0.680 & 0.717 \\
\hline $\mathrm{TK}_{1}$ & & & & 0.831 & & & 0.676 & 0.717 \\
\hline $\mathrm{TK}_{4}$ & & & & 0.815 & & & 0.710 & 0.705 \\
\hline $\mathrm{TT}_{3}$ & & & & & 0.887 & \multirow{4}{*}{0.861} & 0.744 & 0.807 \\
\hline $\mathrm{TT}_{2}$ & & & & & 0.828 & & 0.673 & 0.836 \\
\hline $\mathrm{TT}_{1}$ & & & & & 0.802 & & 0.701 & 0.825 \\
\hline $\mathrm{TT}_{4}$ & & & & & 0.800 & & 0.710 & 0.821 \\
\hline Eigenvalue & 7.061 & 3.266 & 2.413 & 2.012 & 1.417 & & & \\
\hline$\%$ of Variance & 29.422 & 13.610 & 10.054 & 8.385 & 6.137 & & & \\
\hline \multirow{4}{*}{$\begin{array}{c}\mathrm{KMO} \\
\text { Bartlett's Test }\end{array}$} & & & & \multicolumn{2}{|c|}{0.895} & & & \\
\hline & \multicolumn{3}{|c|}{ Chi-Square } & \multicolumn{2}{|c|}{6600.820} & & & \\
\hline & \multirow{2}{*}{\multicolumn{3}{|c|}{$\begin{array}{c}\mathrm{df} \\
\mathrm{Siq}\end{array}$}} & \multirow{2}{*}{\multicolumn{2}{|c|}{$\begin{array}{c}276 \\
0000\end{array}$}} & & & \\
\hline & & & & & & & & \\
\hline
\end{tabular}


We then conducted EFA for dependent variables named brand (TH) and student decision in buying fresh milk (QD). Table 3 shows the analysis results of EFA for two dependent variables TH and QD scales, where we have a cumulative variance of $73.597 \%$, KMO coefficient 0.821 , the significance level of Bartlett's test is less than $1 \%$, indicating that the factor analysis for $\mathrm{TH}$ is appropriate.

Table 3: EFA of TH and QD

\begin{tabular}{|c|c|c|}
\hline \multirow{2}{*}{ Code } & Factor & \\
\cline { 2 - 3 } & $\mathbf{1}$ & \\
\hline $\mathrm{TH}_{1}$ & 0.699 & \\
\hline $\mathrm{TH}_{2}$ & 0.775 & \\
\hline $\mathrm{TH}_{3}$ & 0.721 & \\
\hline $\mathrm{TH}_{4}$ & 0.749 & \\
\hline $\mathrm{QD}_{1}$ & & 0.799 \\
\hline $\mathrm{QD}_{2}$ & & 0.796 \\
\hline $\mathrm{QD}_{3}$ & \multicolumn{2}{|c|}{0.801} \\
\hline $\mathrm{QD}_{4}$ & \multicolumn{2}{|c|}{0.673 .597} \\
\hline Eigenvalue & \multicolumn{2}{|c|}{} \\
\hline$\%$ of Variance & df & 6 \\
\hline \multirow{3}{*}{ KMO } & Sig. & 0.000 \\
\hline
\end{tabular}

\subsection{Confirmatory Factor Analysis (CFA)}

Table 4 shows that the composite reliability coefficients of the scales are all greater than 0.6 and all of the average variances extracted from the scales are greater than 0.5 ; therefore, it could be said that the scales are satisfactory (Hair et al., 1998) to be included in the next analysis.

Table 4: Confirmatory factor analysis (CFA)

\begin{tabular}{|c|c|c|c|c|}
\hline \multirow{2}{*}{ Definition } & \multirow{2}{*}{ Measurement Scale } & \multicolumn{2}{|c|}{ Reliability } & \multirow{2}{*}{$\begin{array}{l}\text { Average } \\
\text { Variance } \\
\text { Extracted }\end{array}$} \\
\hline & & Cronbach & Composite & \\
\hline \multirow{5}{*}{$\begin{array}{c}\text { Factors } \\
\text { influencing } \\
\text { the brand } \\
\text { and student } \\
\text { decision in } \\
\text { buying fresh } \\
\text { milk }\end{array}$} & Product quality (SP) & 0.885 & 0.887 & 0.567 \\
\hline & Fair price (GC) & 0.893 & 0.894 & 0.627 \\
\hline & $\begin{array}{l}\text { Product convenience } \\
\text { (TT) }\end{array}$ & 0.861 & 0.886 & 0.584 \\
\hline & $\begin{array}{c}\text { Promotion and customer } \\
\text { service (CT) }\end{array}$ & 0.839 & 0.846 & 0.531 \\
\hline & Reference group (TK) & 0.875 & 0.876 & 0.640 \\
\hline \multicolumn{2}{|r|}{ Brand $(\mathrm{TH})$} & 0.880 & 0.881 & 0.649 \\
\hline \multicolumn{2}{|c|}{$\begin{array}{l}\text { Student decision in buying fresh milk } \\
\text { (QD) }\end{array}$} & 0.898 & 0.899 & 0.692 \\
\hline
\end{tabular}

Figure 2 shows the results of CFA of the final measurement model (critical model); including: Chi-square = 843.915, df $=443$, P-value $=0.000 ; \mathrm{CMIN} / \mathrm{df}=1.905$ which is less than $3, \mathrm{GFI}=0.911, \mathrm{TLI}=0.954$, and $\mathrm{CFI}=0.959$,
RMSEA $=0.042$, which is less than 0.08. These model parameters well fit the required criteria for CFA; thus, it could be concluded that the model is consistent with the actual data. In addition, these figures also show that the elements investigated in the research model are unidirectional, ensuring convergence values, ensuring reliability and distinct values. The proposed model is consistent with market data.

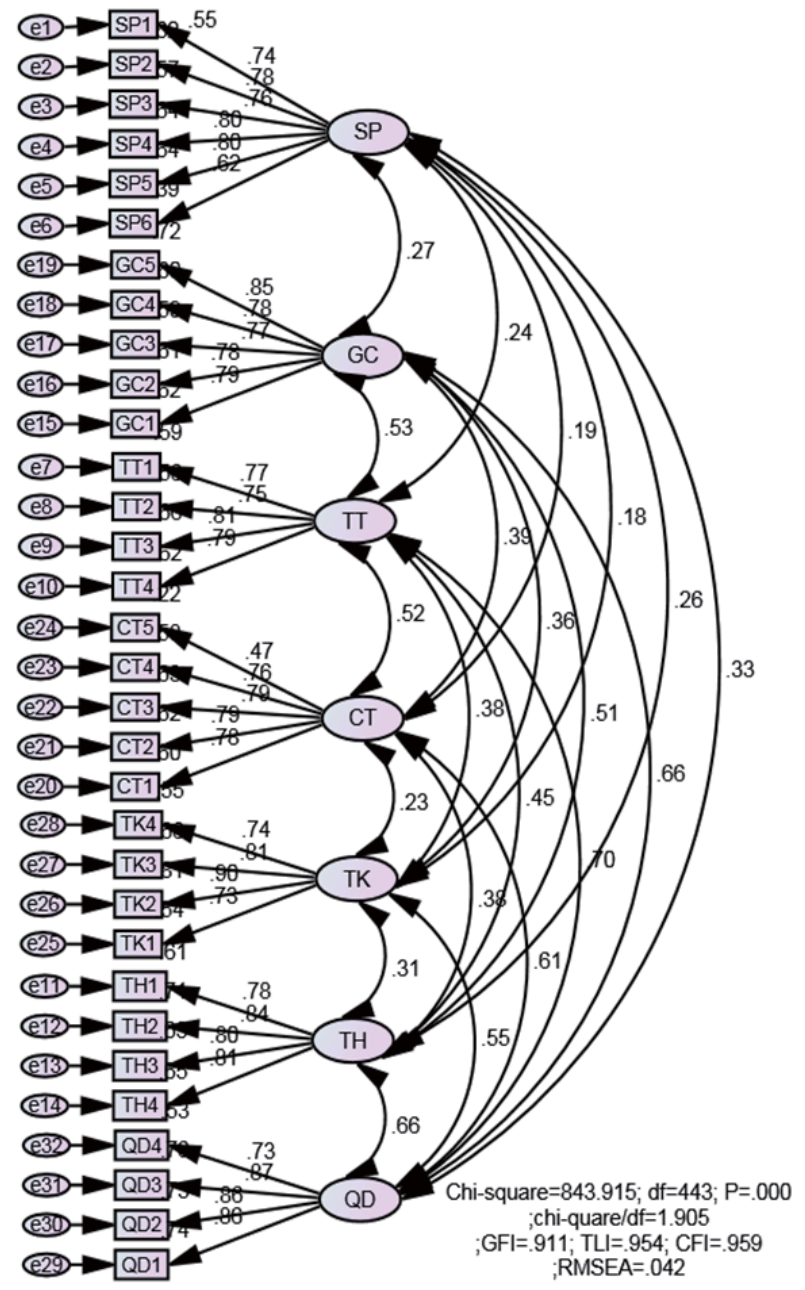

Figure 2: Confirmatory factor analysis (CFA) critical model

\subsection{Structural Equation Modelling}

\subsubsection{Model Testing and Hypotheses}

The estimated results (standardization) in Figure 3 clearly show that the model is consistent with the data. Particularly, Chi-square is equal to 1229.011; df is equal to 453; P-value is equal to $0.000 ; \mathrm{CMIN/df}$ is equal to 2.713 , which is less 
than 3; GFI is equal to 0.868 ; $\mathrm{TLI}$ is equal to 0.913 ; $\mathrm{CFI}$ is equal to 0.921 , all of which are greater than 0.8 ; RMSEA is equal to 0.057 , which is less than 0.08 .

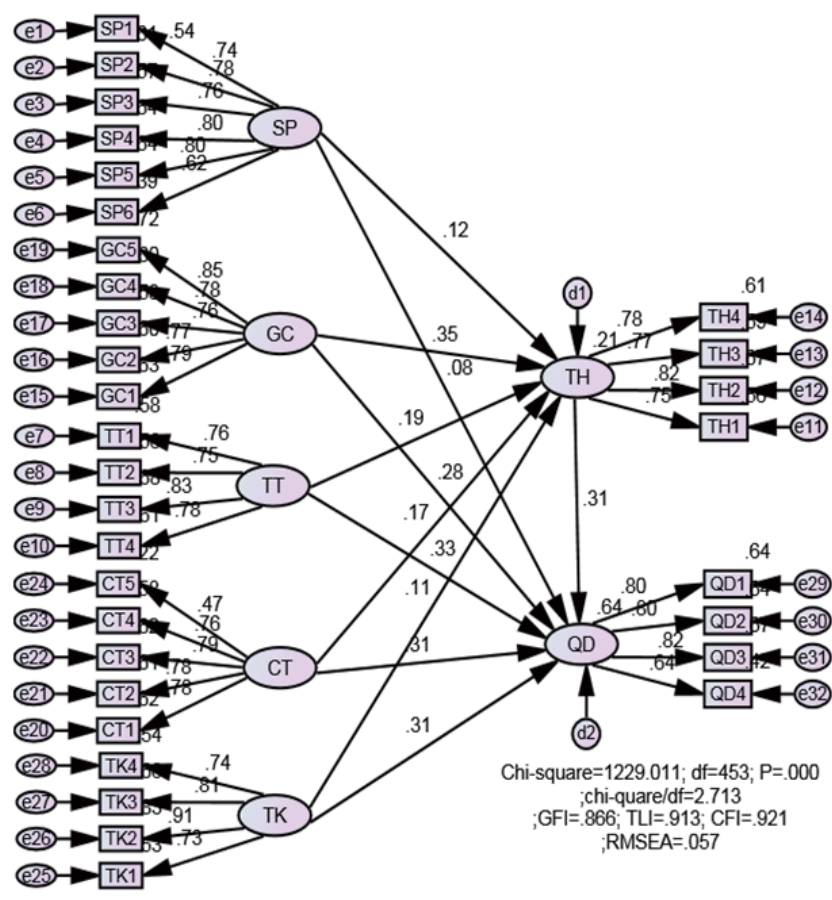

Figure 3: SEM (Standardization) results

\subsubsection{Estimating the Research Model with Bootstrapping}

Using bootstrapping technique with 500 times, we found that the resulted bias was insignificant. Therefore, it can be concluded that the estimates in the model can be reliably verified.

\subsubsection{Estimating the Research Model with SEM}

The results of the research model estimation using SEM analysis shown in Table 5 reveal that the relationship hypothesized in the research model is statistically significant because all $p$-values are less than 0.05 . The hypothesis with the highest $\mathrm{p}$-value is the hypothesis $\mathrm{H}_{6}$, with a value of $\mathrm{p}$ of 0.024 and a significant level of significance (at 95\% confidence). In other words, all the hypotheses $\mathrm{H}_{1}$ to the $\mathrm{H}_{11}$ model are accepted.

\section{Discussion and Managerial Implication}

\subsection{Discussion}

The results show that there are five factors influencing the brand of fresh milk; including fair price (with a coefficient of 0.352), product convenience (with a coefficient of 0.190 ), promotion and customer service (with a coefficient of 0.166 ), quality of the product (with a coefficient of 0.120 ), and reference group (with a coefficient of 0.107 ). Product quality and product price are two among the five factors affecting the brand of the product, which is consistent with that of Cheng and Cheng (2013).

Moreover, we also found that there are six factors influencing the student decision in buying fresh milk; including: product convenience (with a coefficient of 0.330 ), promotion and customer service (with a coefficient of 0.315 ), reference group (with a coefficient of 0.308), brand (with a coefficient of 0.307 ), fair price (with a coefficient of 0.280 ), and product quality (with a coefficient of 0.082 ). This result is partly in line with the study conducted by Bui and Nguyen (2012), who found that the factors that influence purchasing decisions are price, quality, reference group, and others. However, the finding in this study is quite different from other existing literatures in terms of the importance level of the determinants of the student decision in buying fresh milk; specifically, in deciding to buy their fresh milk, students are often interested in the promotion and customer service, the product convenience, and the reference group for the purchase, more than in the quality and price of the product

Table 5: Regression coefficients of the research model

\begin{tabular}{|c|c|c|c|c|c|c|c|c|}
\hline \multicolumn{2}{|c|}{ Relationship } & Coefficient & Standardized Coefficient $(\boldsymbol{\beta})$ & S.E. & C.R. & P-value & Conclusion \\
\hline TH & $<---$ & SP & 0.151 & 0.120 & 0.058 & 2.586 & 0.010 & Accept $\mathrm{H}_{1}$ \\
\hline TH & $<---$ & GC & 0.351 & 0.352 & 0.049 & 7.226 & ${ }^{* * *}$ & Accept $\mathrm{H}_{5}$ \\
\hline TH & $<---$ & TT & 0.175 & 0.190 & 0.044 & 4.004 & ${ }^{* * *}$ & Accept $\mathrm{H}_{7}$ \\
\hline TH & $<---$ & CT & 0.157 & 0.165 & 0.045 & 3.505 & ${ }^{* * *}$ & Accept $\mathrm{H}_{3}$ \\
\hline TH & $<---$ & TK & 0.124 & 0.107 & 0.053 & 2.336 & 0.019 & Accept $\mathrm{H}_{9}$ \\
\hline QD & $<---$ & TK & 0.324 & 0.308 & 0.041 & 7.889 & ${ }^{* * *}$ & Accept $\mathrm{H}_{10}$ \\
\hline QD & $<---$ & CT & 0.274 & 0.315 & 0.034 & 7.935 & ${ }^{* * *}$ & Accept $\mathrm{H}_{4}$ \\
\hline QD & $<---$ & TT & 0.278 & 0.330 & 0.034 & 8.202 & ${ }^{* * *}$ & Accept $\mathrm{H}_{8}$ \\
\hline QD & $<---$ & SP & 0.094 & 0.082 & 0.042 & 2.261 & 0.024 & Accept $\mathrm{H}_{2}$ \\
\hline QD & $<---$ & GC & 0.255 & 0.280 & 0.037 & 6.834 & ${ }^{* * *}$ & Accept $\mathrm{H}_{6}$ \\
\hline QD & $<---$ & TH & 0.281 & 0.307 & 0.041 & 6.901 & ${ }^{* * *}$ & Accept $\mathrm{H}_{11}$ \\
\hline
\end{tabular}


found by Bui and Nguyen (2012) or those by Chigamba and Fatoki (2011), Hong (2015) and Suroto et al. (2013). This is one of the key contributions in our research. From the finding, we propose some managerial implications as the following.

\subsection{Managerial Implication}

Fair price has the strongest impact on the brand $(\beta=$ 0.352 ) and is the fifth most important factor affecting the decision made by students in Ho Chi Minh City to buy their fresh milk $(\beta=0.280)$, indicating that from student's perception, the price is associated with the brand. Thus, the higher the price, the stronger the brand. However, the price affects the student decision differently, i.e. it is ranked 5th in term of importance level. Therefore, managers need to note that price is not the first influence for students. Price is associated with brand, so manufacturers have pricing policies in line with the product line to meet the needs of many different students. To facilitate the choice of dairy products, businesses need to build different price segments and diversity in terms of price. In addition, to encourage students to use their products, firms should have preferential pricing policies for students and stable prices, and their products should be more competitive than other products of the same type. Therefore, the price policies and prices for each product need to be posted publicly, and, in particular, price policies must have discounted levels according to the number of buyers and different customers. Regulatory authorities should also have a price management policy that avoids the speculative impulse to push up dairy prices and unfair competition among dairy firms.

Product convenience has the second highest importance to the brand $(\beta=0.190)$ and is the strongest factor when students in Ho Chi Minh City decide on fresh milk $(\beta=$ 0.330 ). This shows that product convenience is important to the brand and to the student decision to choose fresh milk. Therefore, managers in enterprises should make efforts to build a diversified distribution network, to invest more in freezers and coolers for distribution systems in agents and supermarkets, and to invest more in trucking for distributors, to minimize shipping time and ensure the fastest transit time and a timely response to customer needs everywhere. Firms should open additional showrooms in trade centres to support the distribution network, and should develop more retail outlets. In addition, dairy enterprises must pay attention to the design of the product packaging, which must be easy-to-use and easy and convenient to maintain. Information about the product must be clearly shown. The packaging material must not be harmful to the environment.
The images on the packaging must be attractive to the student age groups.

Promotion and customer service has the third highest importance to the brand $(\beta=0.116)$ and the second highest importance to the decision of students in Ho Chi Minh City to choose fresh milk $(\beta=0.315)$. This shows that promotion and customer service factors are important to the brand and to the student decision to choose fresh milk. Therefore, managers should pay attention to building attractive advertising programmes, regularly organizing programme sponsors and giving gifts to students. Students are young adults, living away from home, and they love new things. Therefore, in order to attract students, businesses need to pay attention to the psychological factors in the branding process, such as impressive advertising programmes, milkdrinking events, and programmes to support scholarships for poor students and high achievers in the universities in Ho Chi Minh City. Besides, in order to take good care of their customers, enterprises need to focus on the level, capacity, and professionalism of the customer service team. The application of technology in management and customer care is a very suitable choice for firms today. Governmental agencies should also adopt appropriate measures to promote the adoption of dairy products for this age group.

Product quality has the fourth strongest level of importance to the brand $(\beta=0.120)$ and the sixth highest importance for the decision of students in Ho Chi Minh City to purchase fresh milk $(\beta=0.082)$. This shows that students are interested in product quality, but that this is not of the greatest importance in deciding to use fresh milk. The quality of a product is often associated with its specific and internal characteristics. Each product is characterized by its characteristics, which are its objective characteristics as manifest in the process of formation and use of that product. Each attribute is represented by certain mechanical, physical, and chemical indicators, which can be measured. Therefore, managers in firms need to show the characteristics of each product, because this is essential to create quality products. To do this, manufacturers need a strategy for developing fresh dairy products to ensure quality and reputation, a variety of designs and types, innovation in quality and design, and environmentally friendly attributes. State regulators should also consider issuing policies and measures to monitor the quality of dairy products in order to ensure that consumers benefit. The Vietnamese government's policy-making bodies should also impose more stringent penalties on dairy firms that do not provide enough milk products to consumers, including students.

The reference group has the fifth strongest level of importance to the brand $(\beta=0.107)$ and is of third importance to the decision of students in Ho Chi Minh City 
to choose fresh milk $(\beta=0.308)$. This shows that students are very interested in other people's opinions when deciding on fresh milk for themselves. Therefore, businesses should pay attention to building exchanges, links, and events with influential groups such as the Student Association, the Ho Chi Minh Youth Union, the Alumni Association, and the centres for student support and counselling of universities in HCMC. In addition, networking between businesses and universities in relation to scholarship grants, staff recruitment, and student recruitment also has a positive effect on students. In addition to these groups, families, relatives and local authorities also strongly affect students' decisions to use dairy products. To attract attention to such objectives, enterprises should pay attention to social responsibility issues such as linking with localities to help disadvantaged people and building houses of compassion. It is a good opportunity, for children who are in difficult circumstances but who are good at studying, to participate in building infrastructure in their local area.

However, this research still has its certain limitations in investigating the students in only two large universities in $\mathrm{Ho}$ Chi Minh City. It would be better if more students from more universities participated in the survey. Besides, there are still many other factors affecting the brand and the student decision in buying their fresh milk. Therefore, our future research would enlarge our participants and consider more affecting factors to develop a more comprehensive approach for wider applications in practice.

\section{References}

Aaker, D.A. (1991). Managing Brand Equity. New York, NY: Free Press.

Aaker, D.A. (1996). Measuring Brand Equity across Products and Markets. California Management Review, 38, 102-120.

Agroinfo (2016). Vietnam dairy sector in 2015 and outlook for 2016, Ha Noi, Vietnam: Information Center for Agriculture and Rural Development (Vietnamese).

Ajay, K., \& Murthi, B. P. S. (2008). When Old Is Gold: The Role of Business Longevity in Risky Situations. Journal of Marketing, 72, 95-107.

Ajzen, I., \& Fishbein, M. (1980). Understanding attitudes and predicting social behaviour. Englewood Cliffs, NJ: Prentice Hall.

Andreti, J., Zhafira, N. H., Akmal, S. S., \& Kumar, S. (2013). The analysis of product, price, place, promotion and service quality on customers' buying decision of convenience store: A survey of young adult in Bekasi, West Java, Indonesia. International Journal of Advances in Management and Economics, 2(6), 72-78.
Bingham, D., Dharmasena, S., Capps, O., \& Salin, V. (2014) Demographic and economic factors affecting demand for brand-level milk in Texas. Retrieved December 18, 2017 from https://ageconsearch.umn.edu/record/162369? In=en

Bolton, R. N., \& James, H. D. (1991). A Longitudinal Analysis of the Impact of Service Changes on Customer Attitudes. Journal of Marketing, 55(1), 1-10.

Bui, T., \& Nguyen, H. (2012) Improve the competitive advantage of the business: Research for the case of supermarkets in Ho Chi Minh City. Ha Noi, Vietnam: Labor and Social Affairs Publishing House (Vietnamese).

Cheng, H. P., \& Cheng, H. T. (2013). The influence of brand and price on purchase intention of mobile phone in the case of Taiwan college students. Proceedings of the 2nd International Conference on Information Technology and Management Innovation (pp. 2326-2329).

Chigamba, C., \& Fatoki, O. (2011). Researching factors affecting the choice of commercial banks university students in South Africa. Journal of Marketing Research, 36(5), 135-148.

Clifton, R., \& Simons, J. (2003). Brand and branding. London, UK: Profile Books Ltd.

Fernandes, S., Chaudhuri, S., \& Vidyasagar, A. (2017). Success crowns Cadbury dairy milk: Brand and culture analysis. International Journal of Applied Business and Economic Research, 15(2), 177-189.

Foxall, G. R., \& Sigurdsson, V. (2013). Consumer behavior analysis: Behavioral economics meets the marketplace. Psychological Record, 63(2), 231-237. DOI:10.11133/j.tpr.2013.63.2.001

General Statistics Office of Vietnam. (2018). List of universities and colleges in Vietnam. Ha Noi, Vietnam: Report of General Statistics Office of Vietnam (Vietnamese).

Goodhope, O. O. (2012). Globalization: The emerging new knowledge economy and consumer behaviour dynamics. International Journal of Academic Research, 4(6), 197203. DOI: 10.7813/2075-4124.2012/4-6/b.31

Hair, J. F., Anderson, R. E., Tatham, R. L., \& Black, W. C. (1998) Multivariate data analysis with reading (5th ed.). Englewood Cliffs, NJ: Prentice Hall.

Hair, J. F., Anderson, R. E., Tatham, R. L., \& Black, W. C. (2006) Multivariate data analysis (6th ed.). Upper Saddle River, NJ: Pearson University Press.

Hong, P. T. (2015). Factors influencing on purchasing formula milk for babies: An empirical research in Hanoi. International Journal of Business Administration, 6(5), 3743.

Investvietnam (2016) Overview Dairy (Vietnamese). Retrieved from goo.gl/HMtofW 
Ishak, S., \& Zabil, N. F. M. (2012). Impact of consumer awareness and knowledge to consumer effective behaviour. Asian Social Science, 8(13), 108-114.

Kotler, P. (1994). Marketing management. Englewood Cliffs, NJ: Prentice Hall.

Kotler, P., \& Armstrong, G. (2010). Principles of Marketing $\left(13^{\text {th }}\right.$ ed.). Boston, MA: Pearson Education, Inc.

Kotler, P., \& Pfoertsch, W. (2006). B2B brand management. Heidelberg, Germany: Springer Berlin.

Kotler, P., \& Keller, K. L. (2016). A framework for marketing management (6th ed.). Harlow, UK: Pearson Education.

Krešíc, G., Herceg, Z., Lelas, V., \& Režek Jambrak, A. (2010). Consumers' behaviour and motives for selection of dairy beverages in Kvarner Region: A pilot study. Mliekajstvo, 60(1), 50-58.

Kuma, B., Baker, D., Getnet, K., \& Kassa, B. (2012). Factors affecting packed and unpacked fluid milk consumption in Wolaita Zone of SNNP Regional State, Ethiopia. Journal of Applied Sciences and Technology, 3(1), 23-31.

Kumar, A., \& Babu, S. (2014). Factors influencing consumer buying behavior with special reference to dairy products in Pondicherry State. International Monthly Refereed Journal of Research in Management \& Technology, 3, 65-73.

Lee, G. C., \& Leh, F. C. Y. (2011). Dimensions of CustomerBased Brand Equity: A Study on Malaysian Brands. Journal of Marketing Research and Case Studies, Article ID 821981. DOI: 10.5171/2011.821981

Lee, H. H., \& Ma, Y. J. (2012). Consumer perceptions of online consumer product and service reviews. Focusing on information processing confidence and susceptibility to peer influence. Journal of Research in Interactive Marketing, 6(2), 110-132.

Leek, S., \& Christodoulides, G. (2012). A framework of brand value in B2B markets: The contributing role of functional and emotional components. Industrial Marketing Management, 41(1), 106-114.

Long, N. T., \& Nguyen, T. L. (2018). Sustainable Development of Rural Tourism in An Giang Province, Vietnam. Sustainability, 10, 953. doi:10.3390/su10040953

McEachern, M. G., \& Schröder, M. J. A. (2002). The role of livestock production ethics in consumer values towards meat. Journal of Agricultural and Environmental Ethics, 15(2), 221-237.

Ministry of Health of Vietnam. (2015). Report the implementation task of the people's health care. Ha Noi, Vietnam: Labor and Social Affairs Publishing House (Vietnamese).

Nguyen T. (2011). Research methodology in business. Ha Noi, Vietnam: Labor and Social Affairs Publishing House (Vietnamese).
Nunnally, J. C., \& Bernstein, I. H. (1994). Psychometric theory (3rd ed.). New York, NY: McGraw-Hill.

Oliveira-Castro, J. M., Cavalcanti, P. R., \& Foxall, G. R. (2016). What Consumers Maximize: Brand Choice as a Function of Utilitarian and Informational Reinforcement. Managerial and Decision Economics, 37 (4-5), 360-371. DOI:10.1002/mde.2722

Padel, S., \& Foster, C. (2005). Exploring the gap between attitudes and behaviour: Understanding why consumers buy or do not buy organic food. British Food Journal, 107(8), 606-625.

Perreau, F. (2014). The Consumer Factor, The Consumer Buying Decision Process. Retrieved December 16, 2017 from http://theconsumerfactor.com/en/5-stages-consumer -buying-decisionprocess/.

Santoso, S., Setiadi, A., Kisworo, A., \& Nuswantara, L. (2012). Analysis various factors that influence the purchasing behavior of goat milk in Bogor Regency, Indonesia. International Journal of Engineering \& Technology, 12(5), 124-131.

Solomon M. R. (2004). Consumer Behavior, Buying, Having, and Being. Upper Saddle River, NJ: Pearson Prentice Hall.

Steenkamp, J. B. E. M., \& Van Trijp, H. C. M. (1991). The use of LISREL in validating marketing constructs. International Journal of Research in Marketing, 8(4), 283299.

Suroto, K. S., Fanani, Z., \& Nugroho, B. A. (2013). Factors influencing consumer's purchase decision of formula milk in Malang City. Journal of Business and Management, 9(3), 95-99.

Thoma, L., Kapaj, A., Boshnjaku, A., \& Muca, E. (2017). Brand awareness and consumer profile for milk: Case of the Tirana market, Albania. Annals of Marketing Management \& Economics, 3(2), 113-119. DOI:10.22630/AMME. 2017.3.2.22

Tuan, L. T., Phuong, N. T. T., Ngoc, L. T. B., \& Mai, L. H. (2013). Powdered milk consumers' buying behaviour. International Journal of Business and Management, 8(2), 29-37.

Vietnam Dairy Association. (2018). Vietnam dairy sector report in 2017. Ha Noi, Vietnam: Labor and Social Affairs Publishing House (Vietnamese).

Vietnam Government. (2011). The decision number: 641/QD-TTg date 28/4/2011 of the Prime Minister about "Master plan for physical strength and height of the Vietnamese people in the 2011-2030 Period (Vietnamese). Zeithaml, V. A. (1998). Consumer Perceptions of Price, Quality, and Value A Means-End Model and Synthesis of Evidence. Journal of Marketing, 52, 2-22. 